DOI: $10.2478 / \mathrm{v} 10014-008-0016-3$

Agrovoc descriptors: brassica oleracea capitata; pest insects; pest control; phyllotreta; thrips tabaci; waxes; defence mechanisms; damage; leaves; injuries

Agris category code: H10; F50; F60

COBISS code 1.01

\title{
Epicuticular wax content in the leaves of cabbage (Brassica oleracea L. var. capitata) as a mechanical barrier against three insect pests
}

\author{
Dragan ŽNIDARČIČ $\check{ }^{1}$, Nevenka VALIČ $\check{~}^{2}$, Stanislav TRDAN ${ }^{3}$
}

Received: August 4, 2008; accepted August 18, 2008.

Delo je prispelo 4. avgusta 2008; sprejeto 18. avgusta 2008.

\section{ABSTRACT}

Flea beetles (Phyllotreta spp.), cabbage stink bugs (Eurydema ventrale) and onion thrips (Thrips tabaci) cause significant economic problems to cabbage growers in Slovenia. The aim of our study was to assess the potential effect of the epicuticular wax on leaves as defence mechanism against these three cabbage pests. The impact of epicuticular wax content in relation to damage levels of cabbage pests was studied under field conditions at the Experimental Field of the Biotechnical Faculty in Ljubljana on 12 cabbage cultivars (Brassica oleracea L. var. capitata). These insect pests showed weak preference on cabbage heads with high epicuticular wax. There was a strong negative relationship between epicuticular wax content and the level of plants infested $\left(r^{2}=-0.8399\right.$ for flea beetles, $r^{2}=-0.7413$ for cabbage stink bugs and $r^{2}=-0.7042$ for onion thrips). The cv.'Holandsko pozno rdeče', showed itself to be the most resistant to the cabbage stink bugs and onion thrips, while cv. 'Red Dinasty' was the most resistant against flea beetles.

Key words: cabbage, Brassica oleracea, flea beetles, Phyllotreta spp., cabbage stink bugs, Eurydema ventrale, onion thrips, Thrips tabaci, epicuticular wax, damage

\section{IZVLEČEK}

\section{VSEBNOST EPIKUTIKULARNIH VOSKOV NA LISTIH ZELJA (Brassica oleracea L. var. capitata) KOT MEHANSKA OVIRA PRED NAPADOM TREH ŠKODLJIVIH ŽUŽELK}

Kapusov bolhač (Phyllotreta spp.), pisana stenica (Eurydema ventrale) in tobakov resar (Thrips tabaci), povzročajo gospodarsko pomembne težave pridelovalcem zelja v Sloveniji. Cilj naše raziskave je bil oceniti potencialni učinek epikutikularnega voska na listih kot obrambnega mehanizma proti naštetim škodljivcem. Vpliv količine epikutikularnega voska na poškodbe, ki jih povzročajo škodljivci, smo proučevali na 12 kultivarjih zelja (Brassica oleracea L. var. capitata), vzgojenih na Laboratorijskem polju Biotehniške fakultete $v$ Ljubljani. Škodljivci so pokazal majhno preferenco do zeljnih glav, ki imajo visoko vsebnost epikutikularnega voska. Med koncentracijo epikutikularnega voska in poškodovanimi listi je bila namreč ugotovljena močno

\footnotetext{
1 M. Sc. Agr., Biotechnical Faculty, University of Ljubljana, SI-1111 Ljubljana, Jamnikarjeva 101; E-mail: dragan.znidarcic@bf.uni-li.si

2 B. Sc., ibid

3 Assist. Prof., Ph. D., ibid
} 
značilna negativna povezava $\left(r^{2}=-0.8399\right.$ za kapusovega bolhača, $r^{2}=-0.7413$ za pisano stenico in $r^{2}=-0.7042$ za tobakovega resarja). Cv.'Holandsko pozno rdeče', se je pokazal kot najbolj odporen kultivar ob napadu tobakovega resarja in pisane stenice, medtem, ko je bil cv. 'Red Dinasty' najmanj odporen proti napadu kapusovega bolhača.

Ključne besede: zelje, Brassica oleracea, kapusov bolhač, Phyllotreta spp., pisana stenica, Eurydema ventrale, tobakov resar, Thrips tabaci, epikutikularni vosek, poškodbe

\section{INTRODUCTION}

Cabbage (Brassica oleracea L. var. capitata) is an important vegetable crop grown in many countries in the world. By far the greatest commercial production of cabbage takes place in Slovenia (Žnidarčič et al., 2007a; Žnidarčič et al., 2007b). The majority of the insect pests on cabbage which are economically important belong to five orders: Lepidoptera, Homoptera, Coleoptera (Stoner, 1992), Thysanoptera (Trdan et al., 2005) and Heteroptera (Trdan et al., 2006). These insect pests can cause damage directly by chewing or sucking sap from leaves and roots or indirectly by transmitting diseases. Moreover, they can also lower the value of the cabbage heads by causing unsightliness such as the presence of insect cast skins and detritus.

Up to a few years ago cabbage growers have relied heavily on insecticides to control insect pests in order to reduce economic losses. However, the heavy use of nonselective insecticides has led to well-known problems, such as development of insect resistance to these chemicals, the resurgence of secondary insect pests, and the persistence of residues that are toxic to humans, animals and other nontarget organisms (Hardin et al., 1995).

Nowadays, the trend in insect control is to decrease the use of conventional insecticides not only because of the cost but also to minimize environmental disruption and avoid the development of pesticide resistance. Plant resistance to insects, integrated with other bio control strategies, should be one of the principal means of nonchemical control of pests (Wiseman, 1994).

Host plant resistance to insect pests is a vital component of integrated pest management (Panda and Khush, 1995) because of low impact on nontarget organisms and the environment. Painter (1951) classified the cause of host plant resistance to herbivores as »non-preference« (renamed »antixenosis« by Kogan and Ortman, 1978), »antibiosis« and »tolerance«.

One of the most promising examples of plant-based resistance (»antixenosis «) is the reduced survival of pests on »waxy« plant species (Eigenbrode and Shelton, 1990; Jenks and Ashworth, 1999; Eigenbrode and Pillai, 1998; Trdan et al., 2005). Waxes differ widely among plant species and among the organs and tissues of a single plant, attesting to the genetic diversity and developmental influences (Rutledge and Eigenbrode, 2003). Plant epicuticular waxes are complex mixtures of primarily very-long-chain aliphatics including primary alcohols (n-alkan-1-ols), aldehydes, 
fatty acids (n-alkanoic acids) and alkyl esters, all of which occur predominantly with even-numbered chain lengths, and hydrocarbons, secondary alcohols and ketones with predominance of odd-numbered chain lengths (Walton, 1990). The chemical composition of the epicuticular wax found on plant surfaces is critically important in the decision of an insect to feed, probe or oviposit on a plant.

Therefore, the aim of the present research was to study the defence mechanism of cabbage cultivars against most phloem-feeding insect pests in Slovenia (flea beetles, Phyllotreta spp., cabbage stink bugs, Eurydema ventrale Kolenati and onion thrips, Thrips tabaci Lindeman) and in particularly the epicuticular wax responses since the epicuticular wax has an important role as antiinsect.

\section{MATERIAL AND METHODS}

Host plant preference trials were conducted at the Experimental Field $\left(46^{\circ} 04^{\prime} \mathrm{N}, 14^{\circ} 31^{\prime} \mathrm{W}, 300\right.$ $\mathrm{m}$ above sea level) of the Biotechnical Faculty in Ljubljana, Slovenia. The field experiment was performed during spring-summer of 2007 on naturally occurring populations.

The trials followed lettuce breakcrops to minimise the detrimental effects of cabbage insect pests and were managed as for high yielding commercial crops. Individual plots consisted of single rows, $40-\mathrm{cm}$ row spacing, each $4.5-\mathrm{m}$ in length, arranged in a randomized complete block design with 12 different cabbage cultivars as treatments ('Vestri', 'Delphi', 'Destiny', 'Green rich', 'Pandion', 'Ixxion', 'Tucana', 'R1-Cross', 'Cheers', 'Red Dinasty', 'Erfurtsko rdeče' and 'Holandsko pozno rdeče').

The plants were single harvested when the majority of the heads reached maturity stage (initiation of the first head splitting). Ten plants in each plot were randomly selected and recorded for damage incidence (percentage of damaged leaf area). Leaves that were attacked by sucking insect pests could be recognized by necrosis and twisting of leaf blades. The frequency of leaves attacked by pests was transformed into damage rating scale according to EPPO directive (OEPP/EPPO, 2002) for Phyllotreta spp., according to Trdan et al. (2006) for Eurydema ventrale Kolenati and according to Stoner and Shelton (1988) for Thrips tabaci Lindeman.

Epicuticular waxes were extracted from the outermost fresh leaves following methodology of O'Neal et al. (2002) and Trdan et al. (2004). As the stage of plant maturity are thought to influence epicuticular wax content, the leaves of similar age were taken and washed in $\mathrm{n}$ hexane for $1 \mathrm{~min}$. The n-hexane extracts were filtered and dried in order to calculate weight of wax. An individual leaf area was measured with an Acer ScanPrisa 1240 UT desktop scanner. The resulting digital pictures were analyzed with the graphics software package Adobe Photoshop 7.0. The leaf area was calculated by transferring pixels to standard units (milimetres). All the results of epicuticular wax represent averages of triplicate determinations and are expressed on a $\mu \mathrm{g} \mathrm{cm}^{-2}$ leaf area.

To examine the effects of host cultivar on the infestation of insect pests, data were analyzed with two-way ANOVA $(P<0.05)$, testing for effects of host cultivar and block. Analyses were carried out on the mean character per plant for each treatment for each block. Comparisons of host cultivars were carried out using Duncan's multiple rang test. A regression analyses was used to determine the relationship between epicuticular wax content and pest damage.

\section{RESULTS AND DISCUSSION}

Infestation of cabbage leaves caused a significant reduction in their dry weights (data not shown). This might be due to the fact that the drain of phloem sap 
assimilates towards the insect away from the other plant parts which may contribute to metabolic reduction (Miles, 1989).

The phloem-sucking insect pests in field tests demonstrated variation in feeding preference among different cabbage cultivars (Table 1). The results of evaluation of the extent of damaged leaf area, caused by feeding of flea beetles (Phyllotreta spp.), on leaves of cabbage showed statistically significant differences between cultivars. The early red cultivars of cabbage 'Red Dinasty' and 'Erfurtsko rdeče' had a significantly lowest number of feeding holes caused by Phyllotreta spp. On the contrary, early white cultivars 'Green rich', 'Tucana' and 'Delphi' had a significantly highest number of feeding holes. Almost similar results were obtained by cabbage stink bugs (Eurydema ventrale Kolenati). The red early cultivars 'Red Dinasty' and 'Erfurtsko rdeče' and red late cultivar 'Holandsko pozno rdeče' were significantly less attractive to Eurydema ventrale Kolenati, while mid-early fresh market cultivar 'Vestri' was significantly the most attractive to Eurydema ventrale Kolenati. By conducting the analysis of the »silver damage rate on outer leaves we were able to demonstrate that the damage is a result of the onion thrips (Thrips tabaci Lindeman) feeding reaching the $7^{\text {th }}$ leaf of the cabbage head. However, the commercially significant damage is between the $2^{\text {nd }}$ and $4^{\text {th }}$ outer leaf of the head (data not shown). Cv. 'Ixxion' (a white cultivar with a very early maturity) was being more susceptible to Thrips tabaci Lindeman than the other cultivars. The index of feeding damaged leaf area by cv. 'Ixxion' was 2.42 . On the other side, the lowest damage rating was found in cv. 'Holandsko pozno rdeče', 'Cheers' and 'Erfurtsko rdeče' with index damaged between 1.12 and 1.23. The weight loss of yield (removed outer leaves) due to insect pest damage on the cabbage heads varied between cultivars. The loss of yield due to damage on the outer leaves from pests was between $6.0 \%$ (cv. 'Holandsko pozno rdeče') to $47.8 \%$ (cv. 'Destiny').

Table 1: Influence of insect pest damage on cabbage heads characteristics

\begin{tabular}{|l|ccc|c|}
\hline \multirow{2}{*}{ Cultivar } & \multicolumn{3}{|c|}{ Damage ratings scale (1-5) } & Removed leaves \\
\cline { 2 - 4 } & Phyllotreta spp. & $\begin{array}{c}\text { Eurydema } \\
\text { ventrale }\end{array}$ & Thrips tabaci & (\% head $\left.{ }^{-1}\right)$ \\
\cline { 2 - 5 } & $1.63 \mathrm{bc}$ & $2.85 \mathrm{c}$ & $1.81 \mathrm{bc}$ & $33.3 \mathrm{~b}$ \\
'Destri' & $1.98 \mathrm{c}$ & $2.50 \mathrm{~b}$ & $2.13 \mathrm{c}$ & $41.1 \mathrm{bc}$ \\
'Destiny' & $1.66 \mathrm{bc}$ & $2.50 \mathrm{~b}$ & $2.00 \mathrm{c}$ & $47.8 \mathrm{c}$ \\
'Green rich' & $1.88 \mathrm{c}$ & $2.50 \mathrm{~b}$ & $2.13 \mathrm{c}$ & $24.5 \mathrm{~b}$ \\
'Pandion' & $1.85 \mathrm{bc}$ & $2.43 \mathrm{~b}$ & $2.18 \mathrm{c}$ & $29.5 \mathrm{~b}$ \\
'Ixxion' & $1.63 \mathrm{bc}$ & $2.41 \mathrm{~b}$ & $2.42 \mathrm{~d}$ & $34.7 \mathrm{~b}$ \\
'Tucana' & $1.96 \mathrm{c}$ & $2.75 \mathrm{bc}$ & $2.30 \mathrm{~cd}$ & $37.9 \mathrm{bc}$ \\
'R1-Cross' & $1.73 \mathrm{bc}$ & $2.48 \mathrm{~b}$ & $1.56 \mathrm{~b}$ & $26.8 \mathrm{~b}$ \\
'Cheers' & $1.78 \mathrm{bc}$ & $2.75 \mathrm{bc}$ & $1.12 \mathrm{a}$ & $9.3 \mathrm{a}$ \\
'Red Dinasty' & $1.26 \mathrm{a}$ & $2.03 \mathrm{a}$ & $1.71 \mathrm{~b}$ & $31.4 \mathrm{~b}$ \\
'Erfurtsko rdeče' & $1.28 \mathrm{a}$ & $2.00 \mathrm{a}$ & $1.23 \mathrm{a}$ & $20.2 \mathrm{~b}$ \\
'Hol. pozno rdeče' & $1.45 \mathrm{~b}$ & $1.98 \mathrm{a}$ & $1.12 \mathrm{a}$ & $6.8 \mathrm{a}$ \\
\hline
\end{tabular}

Within a column, values are not significantly different $(P<0.05)$ if followed by the same letter.

The quantitative comparison of epicuticular wax of cabbage cultivars is shown in Fig. 1. The content of the epicuticular wax in the leaves differs among 12 cultivars tested, but for the most cultivars the content is the lowest between the third and the 
sixth outer leaf in the heads (data not shown). According to Trdan et al. (2005), the value of this potential parameter of plant resistance against phytophagous insects is the highest in the first two outer leaves and grows from the $6^{\text {th }}$ outer leaf of the head towards inside of the head. Overall, a higher concentration of epicuticular wax was present in the leaves of plants of cv. 'Red Dinasty' $\left(48.78 \mu \mathrm{g} \mathrm{cm}{ }^{-2}\right)$, 'Erfurtsko rdeče' $\left(49.25 \mu \mathrm{g} \mathrm{cm}^{-2}\right)$ and of cv. 'Holandsko pozno rdeče' $\left(51.71 \mu \mathrm{g} \mathrm{cm}^{-2}\right)$ compared to other cultivars.

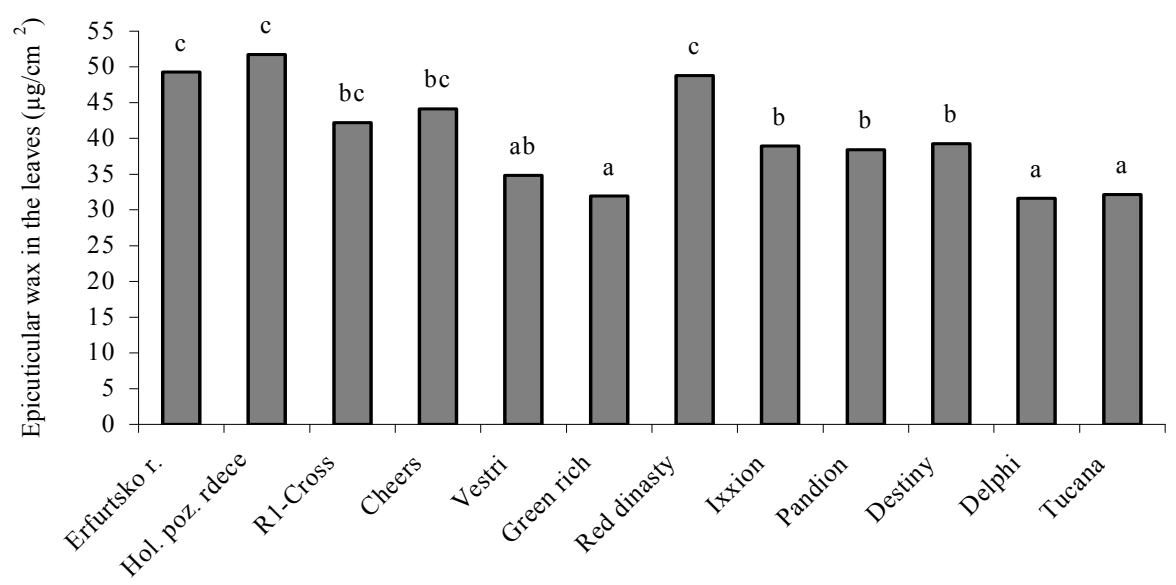

Figure 1: Comparison of epicuticular wax content on leaf surface among different cultivars of cabbage plants. Means within a coloumn followed by the same letter are not significantly different based on Duncan multiple range test $(P<0.05)$.

The damaged cabbage leaves, compared to healthy one, exhibited less epicuticular wax. According to Khattab (2007) such effect may be attributed to the enzymatic effect of insect lipases which digest the wax.

The relationship between the index of leaves damaged and content of epicuticular waxes in leaves is illustrated in Fig. 2. Based on the data, the relationship is satisfactorily described by a linear function of the general form: $y=a x+b$. The mean index of leaves damaged was the dependant variable (y) and the epicuticular waxes was the independent variable (x). The correlation coefficients indicated that there was a close correlation between the two variables. The content of epicuticular waxes in the leaves of cabbage plants correlated negatively with the damaged index of Phyllotreta spp. ( $\left.\mathrm{r}^{2}=-0.8399\right)$, Eurydema ventrale Kolenati $\left(\mathrm{r}^{2}=-0.7413\right)$ and Thrips tabaci Lindeman $\left(\mathrm{r}^{2}=-0.7042\right)$. Insect pest damage to cabbage declined with an increase in epicuticular wax rate. For example, in our research mean Thrips tabaci Lindeman damage was 2.42 for cv. 'Ixxion' at $38.93 \mu \mathrm{g} \mathrm{cm} \mathrm{cm}^{-2}$, but this decreased to 1.12 for cv. 'Holandsko pozno rdeče' at $51.71 \mu \mathrm{g} \mathrm{cm}^{-2}$. 

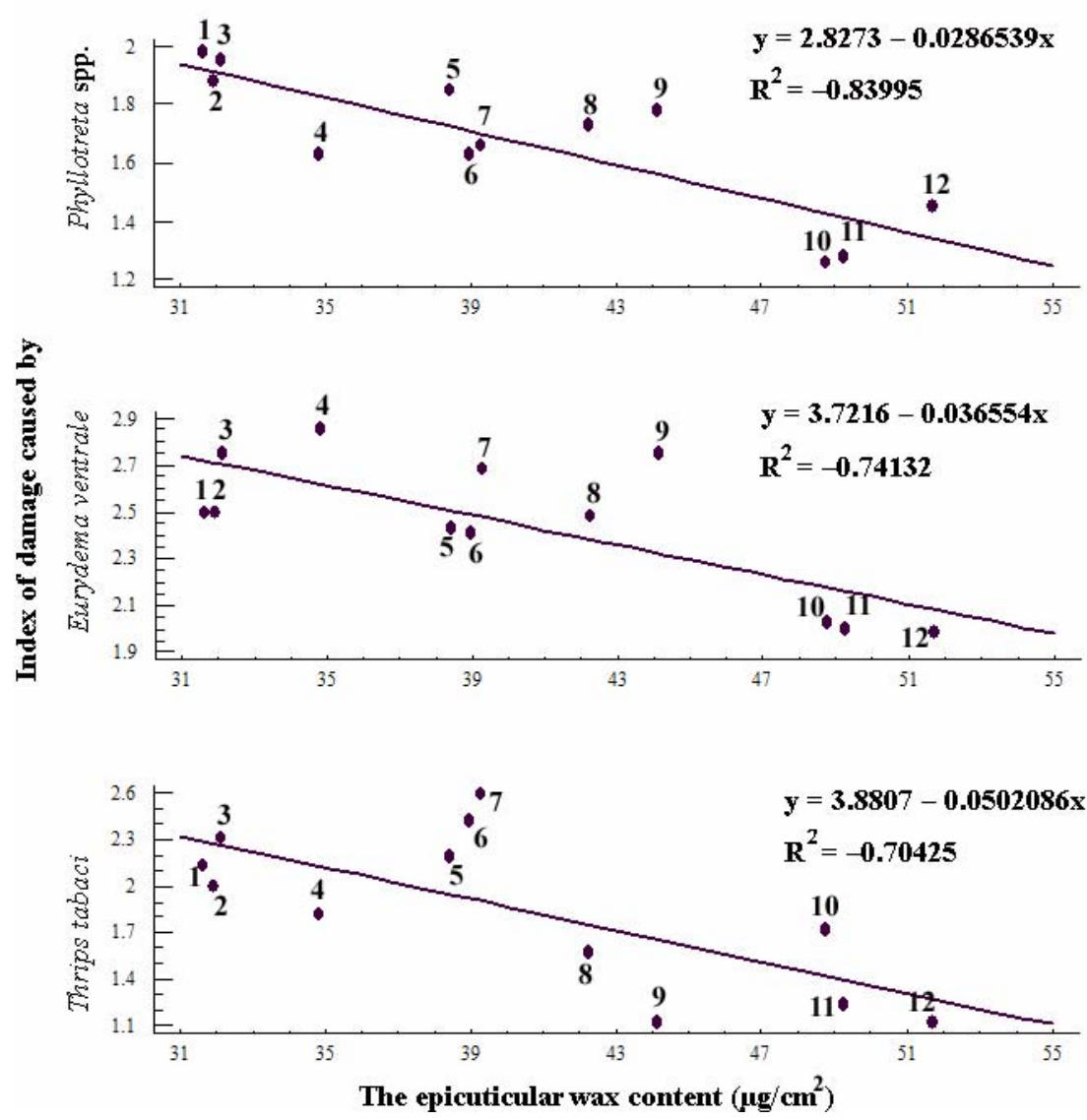

Figure 2: Regression analyses of the relationship of index of leaves damaged to content of epicuticular wax $\left(\mu \mathrm{g} \mathrm{cm}^{-2}\right.$ leaf area) in cabbage leaves. Each

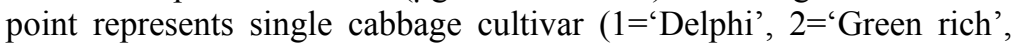
$3={ }^{\prime}$ 'Tucana', $4==^{\prime}$ Vestri', $5==^{\prime}$ Pandion', $6={ }^{\prime}$ 'Ixxion', 7='Destiny', $8={ }^{\prime} \mathrm{R} 1-$ Cross', 9='Cheers', 10='Red Dinasty', 11='Erfurtsko rdeče', $12=$ 'Holandsko pozno rdeče').

There have been a number of reports about insect respond to chemicals on the leaf surface as obtained from experiments using surface extracts of leaves or pure chemicals that are known to occur on leaf surfaces. Sanford et al. (1991), reported that behaviour of neonate diamondback (Plutella xylostella L.), moth larvae on resistant cabbage leaves was affected by leaf waxes. As a conclusion, leaf waxes chemistry and their physical attributes act together with some plant characteristics, to affect neonate diamondback behaviour on cabbage plants. They showed that the larvae spent significantly more time walking, walked more frequently, and walked significantly faster on leaves of $» w a x y \ll$ resistance cabbage than on the susceptible. Stok (1980) reported that mustard beetle (Phaedon cochleariae Fabricius) stick fast to cabbage cultivars that do not have heavy wax bloom than to those with a bloom. 
In »bloom « cultivars, the culm is heavily waxed and the neonate larvae experience considerable difficulty in climbing, their prolegs get stuck in the wax and the larvae never reach the feeding site (Bernays et al., 1983). Our results agree with the findings of Eigenbrode et al. (1999), Gorb and Gorb (2002) and Trdan et al. (2005) who mentioned that epicuticular wax crystals produce the waxy bloom observable on some plant surfaces and epicuticular wax blooms can render plants slippery for insects.

Although results obtained from our experiment provide substantial evidence for epicuticular wax playing a major role in cabbage resistance for insect pests, insect resistance in »waxy « crops is not well understood. It tends not to be expressed reliably in greenhouse or laboratory studies (Eigenbrode, 1990); with the implication that field conditions are necessary. Three factors have been examined. First, reduced epicuticular wax could make plants more vulnerable to water stress, leading to stress-induced increases in defences. This effect helps to explain greater resistance of reduced »waxy« cabbage to the cabbage aphid (Brevicoryne brassicae L.) when the plants are water stressed (Cole and Riggall, 1992). A similar effect may occur for pea aphid (Acyrthosiphon pisum Halliday) on reduced wax pea under xeric conditions (Rutledge et al., 2003). Second, some insect species may prefer plants with relatively prominent epicuticular wax bloom. In contrast to the psyllid (Ctenarytaina spatulata), which prefers Eucalyptus with reduced epicuticular wax bloom (C. eucalypti Maskell) prefers to settle and mate on juvenile leaves of Eucalyptus globuli, which have a prominent epicuticular wax bloom, and rejects adult leaves that have a reduced epicuticular wax bloom (Brennan et al., 2001). A third factor that could cause apparent resistance to insect herbivores on reduced epicuticular wax plants in the field could be related to attachment by their insect natural enemies. Way and Murdie (1965) seem to have been the first to suggest that increased predation on a reduced epicuticular wax crop variety could cause an apparent resistance to herbivores. Epicuticular wax bloom may be the reason why some predators fall frequently or forage ineffectively on plants with epicuticular wax blooms (Kareiva and Sahakian, 1990; Grevstad and Klepetka, 1992). Supporting this possibility, genetically reduced epicuticular wax on cabbage and pea improves the effectiveness and mobility of some predators. In laboratory studies with caged plants, three predator species from three taxonomic orders (Neuroptera; Hemiptera; Coleoptera) kill up to six times more prey (diamondback moth, Plutella xylostella L. on cabbage, or pea aphid, Acyrthosiphon pisum Harris on pea) on a reduced epicuticular wax genotypes of these crops. Each predator species spends a greater proportion of its time walking and falls less frequently from the reduced epicuticular wax plant genotype tested, suggesting that the epicuticular wax blooms disrupt attachment and hence the mobility of these predators.

\section{CONCLUSIONS}

The use of resistant cultivars of cabbage is one of the most effective tools for reducing pest insect damage. In our research we demonstrated that physical characteristics, of cabbage, in particular epicuticular wax content, may have dramatic impacts on pests. We concluded that cultivars of cabbage plants varied not only in their overall levels of antixenotic resistance but also in the form of 
relationship between damage and antixenotic resistance (the norm of reaction to damage). The plant surface waxes influence cabbage insect pests' behaviour and effectiveness and potentially population dynamics. Namely, cabbage leaves exhibited a decline in the rate of epicuticular wax as compared to that of healthy one.

Cultivars that respond at lower levels of damage (such as cv. 'Holandsko pozno rdeče') might have an adventage over cultivars that do not respond until higher levels of damage (such as cv. 'Green rich'), since insect pests could be driven off to other, not-yet-induced plants.

The results of our research could have important implications for the integrated management of insect pests in the commercial production of cabbage in Slovenia. Growing resistant cultivars may not completely eliminate the need for insecticidal intervention, but in the fields where pests' infestations are chronic, implementing these strategies should enable growers to substantially reduce insecticide use in cabbage production.

\section{ACKNOWLEDGMENT}

This research is a part the project financed by the Slovenian Research Agency (ARRS), Ljubljana: "Research on natural resistance of vegetable crops against pests" (J7-7390-0104).

\section{LITERATURE}

Cole, R.A. Riggall, W. 1992. Pleiotropic effects of genes in glossy Brassica oleracea resistant to Brevicoryne brassicae. In: Menken, S.B.J., Visser, J.H. and Harrewijn, P., Editors, 1992. Proceedings of the Eigth International Symposium on InsectPlant Relationships, Kluwer Academic, Dordrecht: 313-315.

Costa, A.A., Varanda, E.M. 2002. Building of Leaf Shelters by Stenoma scitiorella Walker (Lepidoptera: Elachistidae): Manipulation of Host Plant Quality? Neotrop. Entomol., 31, 4: 537-540.

Brennan, E.B., Weinbaum, S.A., Rosenheim, J.A., Karban, R. 2001. Heteroblasty in Eucalyptus globulus (Myricales: Myricaceae) affects ovipositonal and settling preferences of Ctenarytaina eucalypti and C. spatulata (Homoptera: Psyllidae). Environ. Entomol., 30: 1144-1149.

Eigenbrode, S.D., Shelton, A.M. 1990. Behavior of neonate diamondback moth larvae (Lepidoptera: Plutellidae) on glossy-leaved resistant genotypes of Brassica oleracea. Environ. Entomol., 19: 566-571.

Eigenbrode, S.D., Pillai, S.K. 1998. Neonate Plutella xylostella responses to surface wax components of resistant cabbage (Brassica oleracea). J. Chem. Ecol., 24: 16111627.

Eigenbrode, S.D., Kabalo, N.N., Stoner, K.A. 1999. Predation, behavior, and attachment by Chrysoperla plorabunda larvae on Brassica oleracea with different surface waxblooms. Entomol. Exp. Appl., 90: 225-235. 
Gorb, E., Gorb, S. 2002. Contact separation force of the fruit burrs in four plant species adapted to dispersal by mechanical interlocking. Plant Physiol. Biochem., 40: 373-381.

Grevstad, F.S, Klepetka, B.W. 1992. The influence of plant architecture on the foraging efficiencies of a suite of ladybird beetles feeding on aphids. Oecologia, 92: 399404.

Hardin, R.H., Benrey, B., Coll, M., Lamp, W.O., Roderick, G.K., Barbosa, P. 1995. Arthropod pest resurgence: an overview of potential mechanisms. Crop Prot., 14: 3-18.

Jenks, M.A., Ashworth, E.N. 1999: Plant epicuticular waxes: function, production, and genetics. Hortic. Rev. (ed. Janick, J.), John Wiley \& Sons, Inc., N. Y., Chichester, Weinheim, Brisb., Singap., Tor., 23: 1-68.

Kogan, M., Ortman, E.F. 1978. Antixenosis-a new term proposed to define Painter's nonpreference modality of resistance. Bull. Entomol. Soc. Am. 24: 175-176.

Kareiva, P., Sahakian, R. 1990. Tritrophic effects of a simple architectural mutation in pea plants. Nature 345: 433-434.

Khattab, H. 2007. The defense mechanism of cabbage plant against phloem-sucking aphid (Brevicoryne brassicae L.). Aust. J. Basic \& Appl. Sci., 1(1): 56-62.

Miles, P.W. 1989. The response of plant to the feeding of Aphidoidae: Principles. In World Crop Pests (ed.) Minks, A.K. and Harrewijn P. Elsevier, New York (2c): 1-63.

O’Neal, M., Landis, D.A., Isaacs, R. 2002. An inexpensive, accurate method for measuring leaf area and defoliation through digital image analysis. J. Econ. Entomol., 95, 6: $1190-1194$.

OEPP/EPPO. 2002. Guidelines for the efficacy evaluation of insecticides. Phyllotreta spp. on rape. Bull OEPP/EPPO Bull., 32: 361-365.

Painter, R.H. 1951. Insect Resistance in Crop Plants. The University Press of Kansas, Lawrence and London.

Panda, N., Khush, G.S. 1995. Host plant resistance to insects. Wallingford, Oxon OX 10 8DE United Kingdom.

Rutledge, C.E., Eigenbrode, S.D. 2003. Epicuticular wax on pea plants decreases instantaneous search rate of Hippodamia convergens larvae and reduces their attachment to leaf surfaces. Can. Entomol., 135: 93-101.

Sanford, D.E., Espelie, K.E., Shelton, A.M. 1991. Behavior of neonate diamondback moth larvae Plutell xylostella on leaves and on extracted leaf waxes of resistant and susceptible cabbages. J. Chem. Enco., 17: 1691-1704.

Stok, N.E. 1980. Role of wax blooms in preventing attachment to brassicas by the mustard beetle, Phaedon cochleariae. Entomol. Exp. Appl., 28: 100-107.

Stoner, K.A., Shelton, A.M. 1988. Influence of variety on abundance and within-plant distribution of onion thrips (Thysanoptera: Thripidae) on cabbage. J. Econ. Entomol., 81, 4: 1190-1195.

Stoner, K.A. 1992. Density of imported cabbageworms (Lepidoptera: Pieridae), cabbage aphids (Homoptera: Aphididae), and flea beetles (Coleoptera: Chrysomelidae) on glossy and trichome-bearing lines of Brassica oleracea. J. Econ. Entomol., 85: $1023-1030$. 
Trdan, S., Milevoj, L., Žežlina, I., Raspudić, E., Anđus, L., Vidrih, M., Bergant, K., Valič, N., Žnidarčič, D. 2005. Feeding damage by onion thrips, Thrips tabaci Lindeman (Thysanoptera, Thripidae), on early white cabbage grown under insecticide-free conditions. Afr. Entomol., 13, 1: 85-95.

Trdan, S., Žnidarčič, D., Zlatić, E., Jerman, J. 2004. Correlation between epicuticular wax content in the leaves of early white cabbage (Brassica oleracea L. var. capitata) and damage caused by Thrips tabaci Lindeman (Thysanoptera: Thripidae). Acta Phytopathol. Entom. Hung., 39, 1-3: 173-185.

Trdan, S., Žnidarčič, D., Valič, N. 2006. Field efficacy of three insecticides against cabbage stink bugs (Heteroptera: Pentatomidae) on two cultivars of white cabbage. Int. J. Pest Man., 52, 2: 79-89.

Walton, T.J. 1990. Waxes, cutin and suberin. In: Dey, P.M. and Harborne, J.B., Editors. Methods In Plant Biochemistry, pp. 105-158. Academic Press, San Diego, CA.

Way, M.J., Murdie, G. 1965. An example of varietal resistance of Brussel sprouts. Ann. Appl. Biol., 56: 326-328.

Wiseman, B.R. 1994. Plant resistance to insect in integrated pest management. Plant. Dis., 78: 927-932.

Žnidarčič, D., Kacjan-Maršić, N., Osvald, J., Požrl, T., Trdan, S. 2007a. Yield and quality of early cabbage (Brassica oleracea L. var. capitata) in response to within-row plant spacing. Acta agric. Slov., 89, 1: 15-23.

Žnidarčič, D., Vidrih, R., Trdan, S. 2007b. Relationship between water-soluble carbohydrate composition of cabbage (Brassica oleracea L. var. capitata) and damage levels of onion thrips. Acta agric. Slov., 89, 1: 25-33. 